\title{
Euthanasia and Orthodox theology of Communion
}

\author{
VÁCLAV JEŽEK*
}

\begin{abstract}
The article discusses the issue of Euthanasia from the perspective of an Orthodox theology of communion. It demonstrates, that issues related to Euthanasia including moral and ethical issues cannot be limited to the individual and his context, but are in fact issues that should and do incorporate the wider community. The emphasis of Orthodox Theology on Communion and on the community could present possibilities of how to deal with Euthanasia by transferring the debate from the context of the individual and his or her choice or choice of other immediate individuals to an ecclesially centred platform. Just as there is a tendency for greater individualisation in society there is a tendency to moral and ethical individualisation and atomisation.
\end{abstract}

Keywords: Euthanasia, Orthodox Theology, Theology of Communion, Ethics, Morality

\section{Introduction}

In this brief paper we would like to draw attention to the fact that euthanasia, as indeed other forms of suicid too often viewed on a platform of individual decision and on a limited view of the human person. We would like to draw attention to the fact, that euthanasia and suicide are in fact communal events in their essence, both on a practical and theoretical level. We apply some principles of an orthodox theology of communion to the issue and show that the debate on this problem should incorporate wider notions of the community. This stems from the idea that the individual person is not an abstract concept but a person in relation, and his or her suffering or desire for death are indicative of a problem and failings of the community not only the individual. Judgments on the practice of euthanasia have to take this into account and in fact, as the practice itself shows, it is always a communal problem since it involves others and not just the individual at hand.

\section{Preliminary considerations}

Even in ancient thought, the body was often understood as a prison for the soul. ${ }^{1}$ The body's visible corruptibility and the pain associated with it, has

* Václav Ježek, PhD, teacher of Byzantine theology and philosophy at the Orthodox Theological Faculty of the Prešov University, Prešov Slovakia. Address: S.H. Vajanského 44, Michalovce, 07101 , Slovakia; e-mail: vaclavjezek111@gmail.com.

1 The issue of the relation of the body and soul is historically very complex. In this regard one can draw reference obviously to Plato and Aristotle, since both played a major role in the 
stimulated reflections on the relationship between the body and the soul. For some the body was unbearable due to spiritual reasons, as an element hindering liberation of the soul in its quest for perfection, and for others its physical limitations were so unbearable as to call for a re-assessment of the purpose and goal of the life of the human being. For Christians the death of the body was not to be feared due to eschatological reasons. For the non-Christian or atheist, death could mean at least liberation from the body's limits and suffering. In a certain way, euthanasia and all its related issues are also addressing the ancient problem of human suffering and the corruptibility of the body. In both atheism and theism, death is liberation or can be liberation from limits of our body and life. ${ }^{2}$

More significant research needs to be carried out, in order to specify in historical terms cases of voluntary or involuntary death. This is so, since euthanasia seems to be more or less a modern issue, and arguably an issue related to the advances of medicine, which enable the human body to live longer and maintain its functions longer. Thus modern medicine more or less brought with it forms of life's preservation unheard of in previous periods, which however brings about new challenges and ethical issues not dealt with by Christian fathers and theologians.

Of course, murder as such is not unknown to humanity and the murder of the other or others is a fact of humanities history. What one needs to stress here, is that murder is and was often justified for the common good. Wars, the execution of criminals are justified through a communal argument. The murder of the other the individual is thus explained through the prism of the community.

Murder and killing are complex issues and various ideologies could assume a different approach to their justification or understanding. In this

development of later Christian thought and its relation to this problem. An important work by Plato is the Phaedo in this context, where Socrates is not afraid to die, since the release from the body will enable him to contemplate things in a more truthful manner. Aristotle and his work On the soul is also important and in contrast to Plato at least on first glance, Aristotle seems to see the soul and body in a more compact, unified manner. However it remains to be further reviewed whether Plato in his idealism or even Aristotle to a lesser extent truly viewed the body in a negative, one can say, later Gnostic-dualist manner and to what extent their views influenced later negativism to the body if at all in Christian thought. For a general survey see Georges Florovsky, “The 'Immortality' of the Soul,” in: Collected Works, vol. 3, Belmont 1976, p. 213-240.

2 In theism, death could lead to a continuation of life in the afterlife, and in atheism death can lead to a transformation or termination of the body. Both atheism and theism paradoxically can be interpreted in purely positivistic ways in relation to the end of suffering of the body here on earth. 
regard there is no objective humanist principle, which could be brought in. If one was to go by today's egoistic society, what matters is the preservation of the self, or ego, regardless if others are sacrificed or killed. There are many complex situations, which cannot be addressed by simple answers. However, regardless of this, there is a tendency today to fashion some form of universal ethics or principles which arguably fail at the outset since they are often founded on a non-existent foundation or a foundation lacking substance. Thus if one deals with the issue of euthanasia, the question is on what grounds does one build, if he or she wishes to avoid drawing on concrete religious or ethical philosophical systems in the quest for an elusive objectivity.

Euthanasia and its context on one level can be a highly individual problem, which begins on the level of the concrete person, who suffers. But on another level, euthanasia is essentially an issue related to the community at large. Here we see certain schizophrenia; since in the contemporary debate we are faced with one line of argument claiming the right of the individual. However, the rights of the individual are immediately dealt with by the community, its laws and concerns, so the issue is moved to the level of the community regardless of the individual as such.

Indeed, legal concerns have taken prevalence in this issue; and legal systems seem to try to "regulate" an issue which we may say is impossible to regulate by legal means. Thus for example, concepts such as "intention" and "malice" appear in the legal debate. In the English legal system, for example, "English lawyers have often used an artificial sense of «intention" in these contexts, together with technical senses of «malice» to help it out. For in these contexts no weight is given to the distinction between intending death and foreseeing that there is a serious risk of death as a result of one's act." ${ }^{3}$ It is arguable whether these distinctions do in fact help to clarify the ethical and other issues involved.

The legal issues have obviously to do with another issue which is that in any form of death in this context, another party is always present and involved. For example, in assisted suicide the agent, usually being a doctor is very important and he is the ultimate authority deciding on whether the individual should die or not. So it may be the individual's choice to die, but it is a second party which is present and is instrumental in this death (Suicide as such not requiring assistance is obviously something different).

Euthanasia is necessarily linked to the community, since it is a death, where more than just the one person is always involved. Further, we have to

Gertrude Elizabet Margaret Anscombe, Human Life, Action and Ethics, St. Andrews Studies in Philosophy and Public Affairs, Exeter - Charlottesville, 2005, p. 263. 
discern between voluntary euthanasia and involuntary euthanasia. In the first case the person dying consents to his death; in the non-voluntary euthanasia, the will of the person dying is unknown. ${ }^{4}$

As we have indicated the question of agency is important. ${ }^{5}$ Assisted suicide is thus when someone provides you with the means for your death, while euthanasia occurs when the other person brings about your death directly. The third case is that you desire to die, but cannot do so, since you are immobile etc., so someone else has to help you. This is something between assisted suicide and euthanasia. ${ }^{6}$

The debate has two important dimensions. Rights and responsibilities of the individual dying and the rights and responsibilities of the physician or anyone else involved. Sometimes one has the feeling that the debate is clouded by arguments regarding the rights of the individual and the rights and guilt of the person assisting suicide or carrying out this death, and one is confused as to what the issue is here: is it to exonerate the physician or ethically justify one's suicide?

There is a tendency to alleviate the role of the physician who provides the means for assisted suicide. ${ }^{7}$ Some argue that the particular physician is not guilty of anything, since he merely supplies the patient with the necessary means for suicide. More or less in non-religious contexts, the debate seems more to do with the guilt of the person assisting or carrying out the suicide than with the patient.

\section{Pain, suffering and the quality of life}

In this entire debate the substance and nature of pain and suffering are often left unexplored. This is especially so in relation to the Christian context, where we would have expected a more serious reflection. Can one really feel the pain or suffering of the other? The clear cut rejection of euthanasia by Christian theologians would assume so. Often we are presented by Christian arguments, which are very nice and well argued, but of little or no comfort to the person dying. If someone is in severe pain, arguments that he or she is "in the image and likeness of God" seems like a caricature.

However, on the other side, those that argue for euthanasia and related concepts present us with a compassionate face. Proponents for euthanasia argue from a point of view of ultimate compassion; that is, that they perfectly

\footnotetext{
Charles A. Corr et al., Death and Dying, Life and Living, Wadsworth, 2003, p. 489.

Ibidem, p. 488.

6 Ibidem, p. 490.

Ibidem, p. 491.
} 
understand the suffering of the other, and therefore need to act to alleviate this pain. We can argue that both sides really do not understand the suffering of the other, if this means a mere recourse to theoretical presuppositions. In terms of the proponents of euthanasia, we can call attention to the situation in Belgium and Holland where the guidelines on euthanasia are becoming more and more complex. For example, in Belgium the debate is going on, whether a perfectly healthy individual can sign an agreement to terminate his life in the event of him or her being diagnosed with Alzheimer's or dementia. Children can be put to death if they are severely handicapped "to alleviate the suffering of the parents" or the children. The contemporary situation shows, how the practice of euthanasia is being extended and the guidelines blurred in a complex legal discussion. ${ }^{8}$

In fact, there can never be any clear guidelines for understanding pain. For one person a certain pain can be unbearable, while for the other this same pain is bearable. What are then the criteria of unbearable pain and suffering? What are the criteria for compassion, and where is the dividing line between compassion and expediency?

The consideration of pain was always present in Christian history. Many Christian Fathers for example commented on the pain experienced by the parents upon the death of their child. ${ }^{9}$ However to some, the attitude of the Fathers seems almost cynical in their alleviation of the issue. The Fathers often argued that the parents should not be concerned about the death of the child, since death is normal in this life, and that this life is not the final one. Sorrow stems from the fact, that the parents or anyone else simply cannot see the "beauty of seeing Christ's face or the blessings of the afterlife" as the reasoning goes. The Fathers often seem more worried about whether the children were baptized or not, rather than about other considerations. ${ }^{10}$

The patriarch Photios seems to have summarized eloquently these early Christian reflections. In his letter to Tarasios, Patrikos, brother, which is a consolatory letter written on the death of his daughter, Photios writes:

8 See: Judith A. Rienjens et al., "Two Decades of Research on Euthanasia from the Netherlands. What Have We Learnt and What Questions Remain?”, in: Journal of Bioethical Inquiry 6 (3/2009), p. 271-283. Further for more controversial issues and analysis see: Neal Nicol, Harry Wylie, Between the Dying and the Dead: Dr Jack Kevorkian and the Assisted Suicide Machine and the Battle to Legalise Euthanasia, London 2006; Philip Nitschke, Dr Fiona Stewart, Killing Me Softly: VE and the Road to the Peaceful Pill, Penguin Books 2005.

9 See: John Chrysostom, "On Matthew" in: Homily, 31, 4-5, PG 57, p. 375-376; further: "On Death" in: $P G$ 63, p. 804-805, 808; "On II Corinthians Homily" 1,6, PG 61, p. 390392; further for example Gregory of Nyssa, "Homily on Pulcheria" in: PG 46, 868D-869D.

10 See: John Chrysostom, “On the Presbyter" in: PG 61, p. 786. 
"That which has been effected with reference to this blessed young daughter of yours has turned my grief to the opposite, and I deem her blessed for her departure, and I convert my lamentation to the glory of God, and my perplexity to thanksgiving, when I perceive that she has been freed from the circumstances of the present world so auspiciously and just as if one would wish it. [...] But she did not live for a long time. [...] Why does it make any difference if more or less days differentiate our lives when both longevity and brevity transport us to the very gates of death? [...] No one takes pleasure in the past; the future does not exist; the present, in which one might engage in pleasure, is quite brief. [...] Consequently, either a long or a short period of life, since it confines the sensation of pleasurable things only to the present, brings together into the same and similar enjoyment both him who sinks deep into old age and him who flourishes in youth, leading astray the feeling of both by the pleasure of the moment and giving to neither of them a share in pleasure of the past or the future. [...] Consequently, it is a matter of indifference living a long or short time; or rather there is a difference for if no human being is said to be clean from spiritual dirt, and this is seen being confirmed by the facts, even if his life consists of clay in a shorter lifetime departs with less amount, in fact, of bodily stains. [...] On the contrary, one should not mourn for her who has gotten away from her mortal body, but for him who has mortified the immortal mind".

Photios then turns to a standard exposition on suffering by recourse to Job. Suffering is a contest, an agony, perfecting the human person and defeating Satan. "If, however, a demon is laying snares for us and again is asking for a Job, and God permits the malignant one to become a combatant with His servant and tests the latter's patience with a view to reproaching His adversary, and He opens the stadium for contests, on the one hand, to put his opponent to shame and, on the other, to reward the combatant with a crown; not even on this supposition ought one, nor indeed in any wise, to deem the proclamation of virtue as a ground for grief, or to render the time of trophies a time for lamentations or the day of the contest a day of tears. [...] No, I swear by those who have been rewarded with a crown because of their perseverance and the unfading and radiant crowns themselves. [...] Such things are not worthy of your noble soul or steadfast will or remaining excellence" (Demosthenian speech: "Ouk estin, ouk estin opos emartikate, $O$ andres "Athenaioi»"."1

11 Cited from the translation in: Despina Stratoudaki White, Patriarch Photios of Constantinople, His Life, Scholarly Contributions, and Correspondence, with a Translation of Fifty-Two of His Letters, Brookline 1980, p. 117. 
As we have seen Photios offers us a standard reflection on death. Of course, he is not speaking about euthanasia or anything similar, but we can easily transfer his arguments to the issue of suffering and reasons for euthanasia or suicide generally. If Photios saw a patient in palliative care, in agony etc., he would probably comfort him or her, by recourse to similar concerns as expressed in his letter. However, ironically his own formulations could be used to support death, as in the case of children, since as he observes, there is no reason to value one's life solely on its longevity.

In today's world, the widespread view is that suffering and pain are unnecessary, not only in medical terms but in general. Of course, Christians would subscribe to this as well. The argument from physicians and others dealing with patients and ill people who are suffering is that out of compassion and the desire to alleviate pain, one should do all that is possible even if it means death. As we have indicated, to state that one understands the other's suffering and feels compassion, essentially has to mean that one is fully sharing the pain and suffering of the other, which seems to be impossible for anyone except God. Otherwise it is only a partial understanding of the suffering and pain of the other. But this also is true for people like Patriarch Photios or other Christians, who claim to understand the afterlife so well as to be fully competent in relativizing all human suffering and pain. Arguing that one understands fully the pain and suffering of the other is similarly dangerous as arguing that one understands the beauty of the afterlife without having been there. Thus I would argue that unless one fully experiences the pain and suffering of the other, one cannot issue objective arguments on behalf of the other.

Related to the issue of suffering and pain is the issue of the quality of life. There seems to be a tendency in today's world to offer some guidelines for what constitutes and does not constitute a "good life style" or "a good life" and related to this, "a good death". Needless to say, any discussion on the quality of life or the "good life" is highly subjective and any thoughts on this matter will always be tricky just as they are on the subject of euthanasia itself. Any clear-cut distinctions of what is and is not a good life can only lead to confusion, and a fruitless search for objectivity. This aspect of the issue is important, especially if we take into account that pain does not have to be the primary reason for intending to die. Thus for example, from the deaths in Oregon in 2001, which were physician assisted most of the reasons where a loss of the quality of one's life, not pain. ${ }^{12}$

12 A. C. Corr, Death and Dying, p. 509. 


\section{Theology of communion}

What one has to state at the outset is that death and life are still a communal event. Any discussion about death and life, in the Christian perspective and the Orthodox perspective is a discussion in terms of communion and the church. ${ }^{13}$ If we take death or the "good death" (in fact the word euthanasia means this eu-good, thanatos death), in the orthodox perspective we are speaking of death in terms of a theology of communion.

In this regard "the good death" is a death, which could mean suffering, which could mean pain, and could mean loneliness, but can still be a good death. A good death is not merely a comfortable death on the deathbed with pain killers. One may thus ask: Did Jesus die a good death? Did the martyrs die a good death? Of course the martyrs and Jesus did not die a death which should be the necessary form of death for all of us, but their deaths were deaths which, although they encompassed pain and suffering, can still be considered "good" since these deaths were in a way a confirmation of the community and happened through the community. The martyr's death was an expression of their beliefs, of their values for and through the community, the Christian community.

If we look at the funeral services in the Orthodox Church and the previous liturgical traditions of funerals, we can clearly see the communal dimension of dying. The funeral services clearly incorporate an understanding of death, which was understood as a communal event, with people in many ways participating in the death of the individual. The many liturgical formulas, and the entire form of the funeral service presuppose a communal understanding of death (this of course is valid for other sacraments as well).

In an Orthodox theology of Communion, the person is not a mere biological category, but is defined through being in communion with others. A good life or life itself is not something extra added to a biological substance

13 In contemporary Orthodox theology there is an emphasis on the "theology of communion“. The most famous protagonist, needless to say, is John Zizioulas, Communion and Otherness, Further studies on Personhood and the Church, London 2006, or: Idem, Being as Communion, 2004 reprint. The theology of communion is also emphasised by other theologians, which we do not have space to mention. It needs to be said, however, that the emphasis on the theology of communion is not a modern phenomenon in Orthodox thought, but was already developed in the 19th century, especially by Russian orthodox philosophers. Victor Ivanovich Nesmelov can be considered as one of the most substantial contributors to this way of thinking. See: Victor Ivanovich Nesmelov, On the human beingNauka o tcheloveke, Moskva, reprint. 2013. On a more critical note, while highly substantial, a "theology of communion" cannot be adopted without further reflection. In fact, a "theology of communion" implies the existence of a communion. But we have to account for situations where there is no visible human communion. 
or person. Life is being itself, and is expressed through this being. On one level this means that one cannot separate one's life from one's biological being and vice versa. Therefore for example, if one desires to commit suicide, due to the fact that his or her quality of life is decreased, this is a falsity, since the biological nature of the person and his life experiences form a totality, and therefore there is no such thing as a non-existent life or lifestyle, while at the same time a living biological being, which continues to live biologically.

The person as understood by contemporary ideas is a highly relative concept, which produces problems for ethics. This is seen in a simple example. Those that often vehemently argue for the rights of the individual or person, in fact indirectly and subconsciously limit these rights and privileges. For example, one may limit the full development and maturity of the person to certain criteria, such as age, biological characteristics, education and so forth, while at the same time arguing for certain rights and potentials of such a person. Thus those that argue for the right for euthanasia or assisted suicide on the grounds of a decreased quality of life and one's abilities which are lost, immediately limit the concept of that person; they precisely define the person through the prism of some limited concepts of what according to them is the proper quality of life or how should life be. In a more caricatured way, we can reach a conclusion that the person no longer is a person, because he is unable to economically participate in society or to produce money or other things. All this also stems from contemporary societies' inability to view the person in its totality and limit personhood to a working career, to young age etc.

What we seen in fact in debates about euthanasia, are debates which are not only about the individual but about the community. It is not only the individual's choice whether he dies or not, but it actually is also the choice of the community. Thus for example, it is the community (represented by hospital staff or relatives and so on), which decides whether to permit or alleviate the suffering of the individual at hand and is not only the decision of the individual himself or herself. Assisted suicide and euthanasia are in their substance a communal issue, implying more people.

In this regard classifying forms of euthanasia into passive or non-passive does not avoid the fact that whatever forms it takes it still is an event of communion. In terms of passive euthanasia, there is the issue of simply not supplying something to the person, which would prolong his life, but this still is a choice which has to be taken by others. In any event society is involved not only with death but with all other issues related to treatment. We live in a world, where the advances of medical science are not available to all. Not all are able to pay expensive palliative treatment and life preser- 
vation. Not all are able to buy basic medicines and so forth. In this regard compassion to suffering which is often presented as the reason for allowing suicide seems relative, when this compassion is lacking in terms of alleviating the pain and suffering of the population at large, which could be more or less easily prevented.

If we understand the person from an orthodox perspective of a theology of communion, the person is not an autonomous being who is able to decide for himself or herself about his or her existence; if indeed we state that the person is always related to communion and derives its existence from communion. The person as a being formed in the image and likeness of God, who is a God in communion, does not have the autonomy to choose to terminate his being by himself or herself without consequences for the community.

However, having said this one must not fall into idealism. The breakdown of the individual and his ability to live or desire to live is not of his or her making alone. It is a sign that the community has failed. This failure is implied in many ways. For example I find it extraordinary, how often orthodox theologians argue against euthanasia due to many sound theological reasons (image and likeness of God for example etc.), yet fail to acknowledge that this is of no practical interest or avail to the dying and suffering person, if the community also does not follow these principles, and does not attempt to alleviate the pain and suffering of the individual. In theology one has to say A but also B. The individual may in fact be in the image and likeness of God, but he or she is also the image and likeness of the community and is a reflection of its ability to live as a community and care for him or her. If the community fails in its communal aspect, it is not morally justifiable to merely accuse the individual of failing.

In fact, if one visits a hospital, one often sees, that those wishing to die, from one reason or another, do so, often because of loneliness and a lack of interest from their relatives, their surroundings etc. Of course, I do not wish to argue from idealism, that everyone is capable of taking on the other's pain or suffering, and somehow magically alleviating it, or that a suffering patient will immediately change his mind if he or she sees some smiling compassionate face. But simply stated, we are drawing attention to the fact that if the community cannot care for the individual and there is a breakdown between the individual and the community, then the issue is much broader. The failure of one being and person and the failure of his or her desire to live is a failure of the community, not only the individual. One may draw on the ancient theological concept of participation (metochi), which is lacking in the community or in the individual. One fails to participate in the life of the other. 
The issue is even more complicated, if the individual does not have the capacity for free will, or is unable to do anything let alone take his or her life. In terms of practice, one has to take into account the fact if the individual has the capacity to terminate his own life, or if he is dependent on someone else. In many cases people wishing to terminate their lives, would not do this even if they could. Further, there is the important issue of omission of treatment. Some commentators make a distinction between an omission of treatment and adopting treatment. In this case an omission of treatment would mean a lessening of guilt on the part of the physician. The responsibility for euthanasia can lie on the patient or on the doctor. In voluntary euthanasia, the patient can decide; in other forms the doctor's discretion will determine the outcome. The decisions of the community are even more pronounced in this context since the individual is totally dependent on its decision.

Generally death was traditionally viewed as more or less a communal event in many ancient religions. Suffice it to draw attention to the ancient Egyptian religion, where commemoration of the dead, the cult of the dead and the afterlife, were expressions of a life in communion and through communion. In the ancient Greek tradition death means essentially a new communal experience. For example Euripides elaborates on how the dead meet each other in Hades and commune there. ${ }^{14}$

In this context, the Orthodox tradition did in fact treat ways of developing communion primarily through its emphasis on prayer. Prayer as the primary instrument of communion and its expression was adopted as a means of precisely overcoming the negative developments inside the communion and the relationship between the community and the individual. An often neglected fact among commentators is the existence of an entire corpus of prayers, to alleviate pain and suffering before death, contained in the orthodox manuals and "trebniks", which addressed the issue of pain and suffering. Indeed, there are prayers for the quickening of death in these cases.

It is also possible to state, that human life is to be protected due to its being given as a "gift" from the Divine. This may be true, but on the practical level this fact does not help the debate on euthanasia and suffering generally. Already Dostoevsky in his Demons reflected on suicide as a form of ultimate self-control of the human being, who by committing suicide expresses the highest form of free will and challenge to God and "his gift of life". God's expression of love is free and God does not give conditional gifts. Any conditionality in God's gift relates to human choice, since if the human being chooses to die, he or she negates themselves since without love there is no life.

14 See for example his Hecuba 422. 
But this does not mean that love forces itself upon one in terms of a "gift", which cannot be refused. Needless to say, further, for a suffering person, any expressions of life as "God's gift" would not bring comfort.

In terms of theology of communion and the eastern perspective we can emphasize further the richness of ideas gathered in many "funeral orations" in Byzantium, where some notable arguments are expressed. A "funeral oration" in classical thought was already a way of communally dealing with death and suffering. In fact this aspect has not been given any attention by contemporary theologians. As we have implied, while the Fathers of the Church, for example, did not deal with modern issues of bioethics, they in fact dealt with all the human consequences and issues which bioethics touches on. These deserve more reflection from contemporary orthodox theologians who often rely on dialogue with contemporary theories, without a holistic immersion in the way and life of Orthodoxy in previous centuries, which could provide sources of inspiration for contemporary theology.

We do not have the space to further expand on this line of thought. The Byzantine funeral orations as many as they are, as we have already implied, carry some interesting insights. Death and suffering is a "tribute to the law of nature", which cannot be avoided. ${ }^{15}$ Death and suffering is a process through which we regain our true identity and form. Gregory of Nazianzus writes: "This is the meaning of the great mystery for us. This is the intent of God who for our sake was made man and became poor, in order to raise our flesh and restore His image and remake man, that we might all become one in Christ, who perfectly became in all of us all that He is Himself, that we might no longer be male and female, barbarian, Scythian, slave or freemen (Gal. 3:28), the distinctions of the flesh, but might bear in ourselves only the stamp of God by whom and for whom we were made, so far formed and modelled by Him as to be recognized by it alone." 16

The funeral orations were meant as a therapeutic device to comfort those who would suffer in the future or as comfort to those who saw and witnessed the death of someone. In this context Littlewood writes: "The single major difference between the underlying ideas of Byzantine epistolary consolation and the standard modern therapeutic approach is the latter's affective, rather than cognitive, emphasis". ${ }^{17}$

15 Roy J. Deferrari (ed.), "Epitafios logos on his brother, st. Caesarius, Gregory of Nazianzus" in: The Fathers of the Church, New York 1953, p. 19.

16 Ibidem, p. 24, paragraph 23.

17 Antony R. Littlewood, "The Byzantine Letter of Consolation in the Macedonian and Komnenian Periods" in: Dubarton Oask Papers, no. 53, Dumbarton Oaks, 1999, p. 40. 


\section{Conclusion}

From an Orthodox Christian perspective arguments against forms of suicide are more or less straightforward, although this was not the concern of the paper. What we have attempted here, is to draw attention to the dimension of the totality of the human being, a totality incorporating the entire community of which the person is a part. Suicide generally or euthanasia and its related forms, cannot be solely delegated to a discussion on the failure or guilt of the person involved, but should be viewed in terms of the community at large. This is especially so, if one has recourse to traditional theology, which argues, that sin, and other failings are the reasons for a distortion of life in this world and for suffering. A painful death, suffering and so on, are not merely the result of some failure of the individual involved, but are the consequences of the communities failings both on a spiritual level and on a practical one. Theoretical theology devoid of this practical aspect seems cynical. These reflections are useful in the current debate, precisely, since the debate is overly centred either on legal mechanics, or on an individualistic distortion and understanding of the human person. Thus from a practical point of view, if one asks, why does someone want to apply euthanasia etc., one must ask at the same time, where did the community at large fail and what it can do, to modify such a decision or bring about a solution. Ironically, the Orthodox tradition primarily through liturgical means has provided the solution to the problem, through a communal setting on the platform of prayer, which deals with problems of suffering before death (prayers for hastening death etc.). Understanding the experiences of suffering individuals or their general desire to die for whatever reason means an inside approach or a relational approach, which seems to lack in the general discussion on the ethics of euthanasia, which is centred on the individual and the physician etc., as if no one else is involved.

As we have further demonstrated the Byzantine tradition as well as the Orthodox tradition generally had plenty of means to deal with suffering and death in a communal fashion. Suffice it to mention the therapeutic nature of the funerary orations, prayers against suffering and quickening of death in case of suffering. This communal dimension of theology, as well as its therapeutic aspects, needs to be re-discovered by contemporary orthodox theology. The Fathers did not encounter modern theories of bioethics but they surely knew what pain and suffering are and dealt with them in a complex, total and holistic manner, which cannot be reduced to single linear theoretical constructs as often contemporary orthodox theology is asked to do, and which have limited practical influence in the long run. 